The exposure to benzene at different work places in Sweden where petrol is produced or handled has been investigated. The high benzene content ( $\max 5 \%, v / v)$ in Swedish petrol means that many workers are exposed to benzene vapours during their working day. The measurements showed that the exposure of most workers was below the Swedish occupational standard value ( $8 \mathrm{~h}$ TWA, $16 \mathrm{mg} \mathrm{m}^{-3}$ ). Short-time sampling showed the occurrence of exposures to high concentrations above the occupational standard value for $15 \mathrm{~min}$ ( $32 \mathrm{mg} \mathrm{m}^{-3}$ ) among workers at refineries and marketing terminals. Many workers are exposed to benzene via exhaust gases. The concentrations are below the occupational standard value but much elevated compared with the background concentrations of benzene. Precautions to improve the working environment have been suggested.

The annals of occupational hygiene 31 (3), 1987, 345-355

Link to publisher

Part of the licentiate thesis of Rolf Nordlinder, 1989

\title{
EXPOSURE TO BENZENE AT DIFFERENT WORK PLACES IN SWEDEN
}

\author{
Rolf Nordlinder and Olle Ramnäs \\ Chemical Environmental Science, \\ Chalmers University of Technology, Göteborg, Sweden
}

Related articles:

Hazardous petrol hydrocarbons from refuelling with and without vapour recovery Assessment of hydrocarbons in vapours of conventional and alkylate-based petrol 


\title{
EXPOSURE TO BENZENE AT DIFFERENT WORK PLACES IN SWEDEN
}

\author{
Rolf Nordlinder and Olle Ramnäs \\ Chemical Environmental Science, \\ Chalmers University of Technology, Göteborg, Sweden
}

\section{INTRODUCTION}

BENZENE has been and is still a widely used chemical. Because of its health hazards, the use of benzene is avoided with one important exception, namely in petrol, which in Sweden normally contains $4-5 \%(\mathrm{v} / \mathrm{v})$ benzene. The maximum allowable benzene concentration in Swedish petrol is $5 \%(\mathrm{v} / \mathrm{v})$. The total consumption of petrol in Sweden was $4800000 \mathrm{~m}^{3}$ (1983) which gives a total amount of about 190000 tons of benzene.

From the petroleum refineries, the petrol is distributed all over the country through bulk marketing terminals by rail, road or ship and finally reaches the petrol service stations from where it is pumped into the tanks of the cars. Owing to incomplete combustion in the engines of motor vehicles, a small part of the petrol is emitted to the environment in the exhaust gases.

Since evaporated petrol or exhaust gases can be found in the working environment of many different categories of workers, the exposure to benzene is an important problem. The exposure has been studied by several authors (BERLIN et al., 1974; BERLIN and TuneK, 1981; Brief et al., 1980; Collegium RamazzInI, 1985; CONCAWE, 1981; IrWING and Grumbles, 1979; Nordic EXPERT Group, 1981; Parkinson, 1971; PHILlIPS and JoNES, 1978; SHERWOOD, 1972). A recent review of benzene exposures in the oil industry, covering data from all European countries, is given in CONCAWE (1986). In the present work the exposure to benzene has been studied at important emission places along the Swedish distribution chain.

\section{Health effects}

High concentration of benzene affects the central nervous system and causes the same acute exposure effects as most organic solvents. Common symptoms are dizziness, irritability, nausea, insomnia, tiredness and headache. The acute effects are normally short-term and decrease when the exposure is finished. Generally, acute exposure effects are considered to be reversible, while chronic exposure effects are probably irreversible (CHEREMISINOFF and MORRESI, 1979). 
Long-term exposures to low concentrations of benzene damage the hematopoietic system (SNYDER and Kocsis, 1975). The adverse effects of benzene on bone marrow have been known since before the turn of this century (SANTESSON, 1897). Leukemia related to benzene exposure has been found among shoe workers (VIGLIANI and FORNI, 1976) and in the rubber industry (INFANTE et al., 1977).

It has been difficult to demonstrate benzene carcinogenicity in animal exposure experiments. A long-term bioassay showed that benzene is a multi-potential carcinogen, producing a variety of tumours (MALTONI et al., 1983). Cytogenetic effects of benzene have been demonstated with micronucleus tests on bone marrow from mice (HITE et al., 1980). There has also been evidence that low levels of benzene affect human immuno-defence (LANGE et al., 1973). The adverse effect on the immunological system may explain why benzene intoxicated individuals readily succumb to infections. The terminal event in severe benzene poisoning can be an acute overwhelming infection (SNYDER and Kocsis, 1975).

Benzene has also been shown to be fetotoxic with such effects as decreased weight gain and skeletal abnormalities (GREEN et al., 1978). Teratogenic effects have not been documented yet, but negative results in animal studies are not conclusive proof for no effects in humans.

There has been, and there is still, a debate in the United States about the occupational standard value of benzene ( $8 \mathrm{~h} \mathrm{TWA}, 30 \mathrm{mg} \mathrm{m}^{-3}$ ) (ZENZ, 1978), because an increased number of chromosomal changes has been shown for workers exposed to benzene at levels below $30 \mathrm{mg} \mathrm{m}^{-3}$ (EPA, 1978; PICCIANO, 1979).

\section{MATERIALS AND METHODS}

The exposure to benzene and alkylbenzenes has been measured with a technique of sampling and analysis developed at our department (NORDLINDER and RAMNÄs, 1981). We have used it for measurements in different working environments since 1978. The method is based on adsorption of the hydrocarbons on a porous polymer (Tenax GC or TA), followed by thermal desorption and gas chromatography. Only commercially available gas chromatographic equipment is used. The thermal desorption technique combined with capillary gas chromatography increases the sensitivity more than 500 times compared with the solvent desorption method. The high sensitivity allows measurements of very low concentrations (MATTSSON and Petersson, 1982; Petersson, 1982).

The individual exposures of employees were measured using personal sampling with Tenax tubes and personal sampling pumps, followed by heat desorption into a gas chromatograph, except during road tanker loading, when the benzene concentration also was continuously measured with a portable i.r. spectrophotometer (Miran 1A).

\section{RESULTS AND DISCUSSION}

Work at a petroleum refinery

At a petroleum refinery thousands of possible emission sources of hydrocarbons exist, e.g. flanges, pumps, valves, etc. In the working environment a very complex mixture of hydrocarbons of varying toxicity can be found. 
The exposure to benzene was measured for different categories of refinery workers (Table 1). The Swedish occupational standard value for benzene $(8 \mathrm{~h}$ TWA, $16 \mathrm{mg} \mathrm{m}^{-3}$ ) was not exceeded. Laboratory workers occupied with product sampling and cleaning of sampling equipment exhibited the highest exposure. It is notable that workers at the crude oil distillation unit were more exposed than workers at the reformer unit, despite the fact that the benzene concentration was higher in the reformate than in the crude oil.

Measurements during special types of jobs were also carried out. The high sensitivity of the method allows short-time sampling. This is important, because high exposure jobs of short duration make considerable contributions to the average exposure during the day. Reduction of the exposure during these jobs would effectively lower the total benzene dose during the workday. High benzene concentrations were found at the crude oil distillation unit during control of the level in the desalter and during stream sampling of products. The highest benzene concentration measured was $190 \mathrm{mg} \mathrm{m}^{-3}(5 \mathrm{~min})$. In this case the exposure could easily be lowered by improving the sampling technique. Passing the product stream through a cooling loop before sampling would reduce the exposure more than 10 times. Systems for reducing the exposure during stream sampling have been described (GITZLAFF et al., 1979).

The high resolution in the chromatographic analysis of the hydrocarbons is an important tool when the source of exposure is to be determined. Depending on the origin of the exposure, the ratio of the concentrations of hydrocarbons will be different. A sample taken when petrol is evaporated from the surface of a bulk liquid is different from that obtained when petrol is completely vaporized (Fig. 1). In the first case the low boiling components will dominate and in the second case the ratio will be the same as for liquid petrol. Also, there will be an accentuation of the higher boiling point components in the vapour evolved during the final stages of evaporation of petrol spilled on the floor or clothing.

The relative concentrations of benzene, toluene and xylenes (the sum of $m-, p$-and $o$-xylene and ethylbenzene) have been calculated for different types of refinery jobs (Table 2). The results show differences that may be attributed to different evaporative conditions, as mentioned above.

\section{Petrol transport and storage}

The products from the refinery are distributed by rail, road or ship. The exposure to benzene has been measured during petrol loading at bulk marketing terminals and in the harbour. The vapours escaping from the tanks during filling were the main source of exposure, but spillages and leakages were also of importance.

Rail tanker loading. The exposure to benzene during loading of rail tankers was studied at a refinery. Only bottom loading without a vapour recovery system was used. Two men worked at the terminal, one on the top of the tanks inspecting the levels and the other on the ground connecting the loading vessels. The benzene concentration to which they were exposed varied between 0.2 and $10 \mathrm{mg} \mathrm{m}^{-3}$ (Table 3). Owing to bad equipment the man on the ground exhibited the highest exposure. Each time the hose was disconnected, the contents of the hose flowed out onto the ground. The exposure of the workers could be lowered by improving the hose connections and by using an automatic level indicator instead of manual inspection. 
TABLE $1.8 \mathrm{~h}$ TWA EXPOSURE LEVELS $\left(\mathrm{mg} \mathrm{m}^{-3}\right)$ OF DIFFERENT CATEGORIES OF REFINERY WORKERS TO BENZENE

\begin{tabular}{lcc}
\hline \multicolumn{1}{c}{ Type of work } & Mean & Range \\
\hline Crude oil distillation unit $(N=4)^{*}$ & 0.8 & $0.5-1.3$ \\
Reformer unit $(N=3)$ & 0.2 & $0.1-0.3$ \\
Sampling and cleaning & & \\
at laboratory $(N=3)$ & 1.0 & $0.3-2.0$ \\
Product analyses at & 0.2 & \\
laboratory $(N=1)$ & 0.1 & \\
Power plant workers $(N=1)$ & \\
\hline
\end{tabular}

${ }^{*} N=$ number of samples.

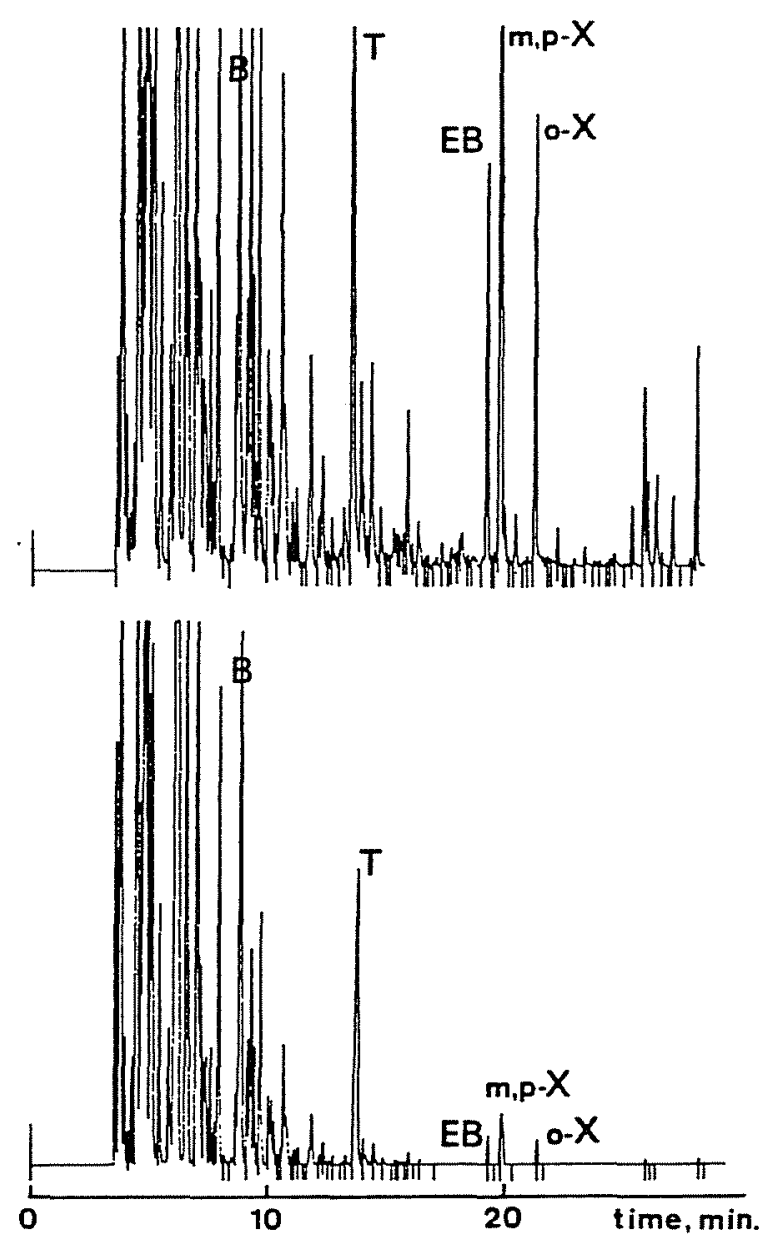

FIG. 1. Comparison of the 'hydrocarbon pattern' from the gas chromatographic analysis of liquid petrol (upper chromatogram) and of the gas phase over the surface of liquid petrol (lower chromatogram). $\mathrm{B}=$ benzene, $\mathrm{T}=$ toluene, $\mathrm{EB}=$ ethylbenzene, $\mathrm{m}, \mathrm{p}-\mathrm{X}=m$ - and $p$-xylene, $\mathrm{o}-\mathrm{X}=0$-xylene.

Road tanker loading. Top loading and bottom loading at different bulk marketing terminals for road tankers was investigated. No vapour recovery system was installed at any terminal. The exposure varied greatly, depending on the design of the terminal, e.g. open or enclosed, the meteorological conditions and the method of working. Concentrations around $1-10 \mathrm{mg} \mathrm{m}^{-3}$ were measured during top loading at open 
TABLE 2. RELATIVE CONCENTRATIONS ( $w / w$ ) OF BENZENE, TOLUENE AND XYLENES IN THE BREATHING ZONE DURING DIFFERENT TYPES OF REFINERY WORKS*

\begin{tabular}{lcccc}
\hline \multicolumn{1}{c}{ Type of refinery work } & \multicolumn{5}{c}{$\begin{array}{c}\text { toluene/benzene } \\
\text { Ratio }\end{array}$} \\
& Mean & Range & xylenes/benzene \\
Mean & Range \\
\hline $\begin{array}{l}\text { Crude oil distillation unit } \\
\text { Level checking at desalter }(N=4) \dagger\end{array}$ & 0.5 & $0.3-0.8$ & 0.5 & $0.3-0.9$ \\
Stream sampling of products $(N=6)$ & 0.3 & $0.1-0.6$ & 0.3 & $0.2-0.3$ \\
Inside cabin $(N=4)$ & 1.4 & $0.7-2.2$ & 2.5 & $0.7-6.8$ \\
TWA 8-h $(N=4)$ & 0.4 & $0.3-0.6$ & 0.3 & $0.2-0.4$ \\
Reformer unit & & & & \\
Stream sampling of reformate $(N=3)$ & 2.4 & $2.3-2.5$ & 3.2 & $2.0-4.5$ \\
Inside cabin $(N=2)$ & 1.3 & $0.9-1.7$ & 1.4 & $0.9-1.8$ \\
TWA 8-h $(N=3)$ & 1.1 & $1.0-1.3$ & 1.4 & $1.0-2.1$ \\
Laboratory & & & & \\
Reformate sampling from tanks $(N=1)$ & 2.6 & & 1.4 & \\
Cleaning of sampling equipment $(N=3)$ & 1.3 & $1.1-1.6$ & 1.4 & $0.9-2.2$ \\
TWA 8-h $(N=3)$ & 1.7 & $1.2-2.2$ & 1.3 & $0.6-1.9$ \\
\hline
\end{tabular}

$*$ Benzene $=1.0$.

$\dagger N=$ number of samples.

TABLE 3. BENZENE CONCENTRATION $\left(\mathrm{mg} \mathrm{m}^{-3}\right)$ IN THE BREATHING ZONE OF WORKERS OCCUPIED WITH PETROL DISTRIBUTION. SAMPLING TIME BETWEEN 5 AND 15 MIN

\begin{tabular}{lcc}
\hline \multicolumn{1}{c}{ Type of distribution } & Mean & Range \\
\hline $\begin{array}{l}\text { Rail tanker loading (bottom loading) } \\
\text { Operator on top of tank }(N=3)^{*}\end{array}$ & 0.7 & $0.2-1.6$ \\
Operator on the ground $(N=3)$ & 4.4 & $1.4-10$ \\
Road tanker loading & & \\
Top loading & & \\
$\quad$ open terminal building $(N=16)$ & 4.3 & $1.0-13$ \\
$\quad$ closed terminal building $(N=5)$ & 22.0 & $7.0-54$ \\
Bottom loading & 3.0 & $0.5-4.0$ \\
$\quad$ open terminal building $(N=6)$ & 6.9 & $0.2-24$ \\
$\quad$ closed terminal building $(N=6)$ & & \\
Ship loading & 107 & $19-365$ \\
Manual sounding $(N=8)$ & 9.6 & $2.7-20$ \\
Crew on deck $(N=3)$ & & \\
\hline
\end{tabular}

${ }^{*} N=$ number of samples.

terminals (Table 3). At terminals with buildings which give rise to less effective natural ventilation benzene concentrations up to $50 \mathrm{mg} \mathrm{m}^{-3}$ were found. The top loader, who should but does not always wear a personal respirator, is exposed to the vapours escaping from the manhole when checking the level in the tank. By recording the hydrocarbon concentration continuously with a portable i.r. spectrophotometer it was seen that the concentration increased markedly during the very late phase of the loading, 2-5 times higher than during the early phase.

At open terminals bottom loading gave in most cases lower exposures, $0.5-5 \mathrm{mg} \mathrm{m}^{-3}$. The exposure arises from heavy vapours flowing down the side of the 
tank, especially when the weather is calm. Spillage and leakage also contribute to the exposure at bottom loading.

The exposure could be lowered considerably if a closed loading system were installed. Until this is done, the loader should protect himself by wearing an effective respirator and by trying to keep his breathing zone out of the vapour plume. It is notable that the tanker driver generally loaded his own vehicle.

Ship loading. Samples taken during petrol loading on to small tankers showed that some members of the crew were heavily exposed to benzene (Table 3 ). Those who worked with manual sounding of the tanks exhibited very high short-term exposure, up to $400 \mathrm{mg} \mathrm{m}^{-3}$. During sounding it is difficult for the worker to keep out of the vapour plume from the manhole. The benzene concentration in the plume was between 1000 and $10000 \mathrm{mg} \mathrm{m}^{-3}$. The highest concentration was obtained during the very late phase of the loading when the tanks were topped up. During this phase the level must be checked more frequently than earlier and the exposure will then be extremely high. The vapours escaping from the tanks spread all over the deck and also gave rise to considerable exposure for crew members not directly occupied with the loading. Increased exposure was even measured for workers on the quay in the vicinity of the tanker.

A reliable automatic sounding system would lower the exposure for some members of the crew to a considerable extent, as would a vapour recovery system that permitted enclosed loading operations.

\section{Petrol pump service}

Two categories of workers occupied with control and maintenance of petrol pumps have been studied. In the first category are the official adjusters who once a year have to check that the true volumes are delivered from the pumps and in the second are the petrol pump mechanics doing small repairs at the petrol service station and more extensive repairs in a central workshop. The concentration of benzene has been measured during different types of jobs (Table 4). The exposure to benzene was rather high, but the occupational standard value was not exceeded. The highest exposure occurred in the repair shop during work with petrol-soaked parts. Spillage and leakage were important sources of exposure at the petrol service stations. The exposure depended very much on the weather conditions. A hot day with no wind represented the worst conditions.

The benzene exposure ( $8 \mathrm{~h} \mathrm{TWA}$ ) of mechanics $\left(0.8 \mathrm{mg} \mathrm{m}^{-3}\right)$ was higher than that of adjusters $\left(0.4 \mathrm{mg} \mathrm{m}^{-3}\right)$. This difference probably rests on the fact that mechanics keep their standards, tools and spare parts inside their cars, while adjusters keep them in a trailer. The relative concentrations of benzene and alkylbenzenes in the car were similar to what could be expected if the main source of exposure of the mechanics were petrol evaporated inside it.

\section{Garage workers}

The benzene exposure of mechanics and motor electricians was measured in seven garages during different operations. More than 100 samples were taken. The average exposure levels ( $8 \mathrm{~h}$ TWA) were calculated from these samples and from the knowledge of the distribution of different working stages during a typical working day (Table 5). 
TABLE 4. CONCENTRATION ( $\mathrm{mg} \mathrm{m}^{-3}$ ) OF BENZENE IN THE BREATHING ZONE AT PETROL PUMP SERVICE. SAMPLING TIME = TIME OF OPERATION

\begin{tabular}{lc}
\hline \multicolumn{1}{c}{ Type of work } & $\begin{array}{c}\text { Concentration } \\
\left(\mathrm{mg} \mathrm{m}^{-3}\right)\end{array}$ \\
\hline $\begin{array}{l}\text { Work at petrol station } \\
\text { Pumping, no adjustment of piston (sampling time 20 min) }\end{array}$ & 0.5 \\
Pumping, adjustment of piston (sampling time $20 \mathrm{~min}$ ) & 0.7 \\
Pumping, overflow (sampling time $15 \mathrm{~min})$ & 1.8 \\
Changing of counter (sampling time $60 \mathrm{~min})$ & 2.1 \\
Work in central workshop & \\
Dismantling of pump body (sampling time $40 \mathrm{~min})$ & 2.0 \\
Dismantling of filter (sampling time 10 min) & 20 \\
\hline
\end{tabular}

Since the distribution of operations can vary quite a lot from one day to the other, it is difficult to give a meaningful value of the range of the exposure.

The benzene concentration was higher in small garages than in large garages. The ventilation in small garages is generally insufficient and good ventilation is obtained only during the summer when the doors are open. Exhaust gases and evaporation of spillages, etc., increase, of course, the concentration in the air much faster in a small space than in a large one. The benzene concentration increased almost as a linear function of the total number of cars driven into or out of the garage. In our experience, portable catalytic exhaust gas cleaners did not work very well, generally because of bad maintenance (temperature too low, no change of catalyst, etc.).

The exposure in garages depends both on the background concentration of benzene due to the diffuse emission from many sources and on the increased concentration during 'petrol work' (e.g. work with fuel injection systems, petrol tanks, etc.). During the winter the background contributes to $65 \%$ of the benzene exposure of the mechanics. With improved ventilation in the summer, this contribution is lowered to $25 \%$. For motor electricians the background contribution is less important, $40 \%$ during the winter and $10 \%$ during the summer. In order to improve the working environment it is therefore most important to decrease the exposure during 'petrol works'. Measurements were taken during typical 'petrol works' (Table 6). The motor electricians are exposed to elevated benzene concentrations during the adjustment of direct fuel injection systems. When adjusting the spraying nipples petrol is sprayed out in the engine house. The work must be done with a warm engine and when the petrol droplets reach the hot exhaust manifold they are immediately vaporized. A plastic cover over the nipples reduced the exposure by $50 \%$ (Table 6 , sample E). The number of cars with fuel injection is increasing and it is therefore of great importance to reduce exposure during this type of work. Dismantling of the cylinder head also caused high exposure (Table 6, sample C), mainly because the carburettor was not emptied beforehand. Another job giving rise to high exposure is draining the petrol tank. The contents are often poured into an open vessel, but when a petrol can was used the exposure was lowered significantly (Table 6, sample F).

\section{Cleaning of heating-oil tanks}

Tanks for heating-oil in houses have to be cleaned inside about every fifth year. Despite the low benzene content in heating oil $(<0.5 \%)$, benzene concentrations of 
TABLE 5. COMPARISON OF THE $8 \mathrm{~h}$ TWA EXPOSURE LEVELS ( $\mathrm{mg} \mathrm{m}^{-3}$ ) OF MECHANICS AND MOTOR ELECTRICIANS TO BENZENE AT DIFFERENT TYPES OF GARAGES DURING SUMMER AND WINTER. THE LEVELS ARE CALCULATED FROM MORE THAN 100 SAMPLES TAKEN DURING DIFFERENT WORKING STAGES AND FROM THE DISTRIBUTION OF THESE STAGES DURING A TYPICAL WORKING DAY

\begin{tabular}{lc}
\hline \multicolumn{1}{c}{ Type of garage } & $\begin{array}{c}\text { Concentration } \\
\left(\mathrm{mg} \mathrm{m}^{-3}\right)\end{array}$ \\
\hline $\begin{array}{l}\text { Small garages } \\
\text { (mechanics/motor electricians) }\end{array}$ & \\
$\quad$ Summer & 1.6 \\
$\quad$ Winter \\
Medium and large garages & 6.8 \\
$\quad$ Summer & \\
mechanics & \\
electricians & 0.4 \\
Winter & 1.0 \\
mechanics & \\
electricains & 0.8 \\
\hline
\end{tabular}

TABLE 6. CONCENTRATION OF BENZENE IN THE BREATHING ZONE DURING DIFFERENT TYPES OF JOBS IN GARAGES

\begin{tabular}{|c|c|c|}
\hline Sample & $\begin{array}{l}\text { Sampling time } \\
(\min )\end{array}$ & $\begin{array}{l}\text { Concentration } \\
\left(\mathrm{mg} \mathrm{m}^{-3}\right)\end{array}$ \\
\hline A. Carburettor adjustment & 15 & 1.2 \\
\hline B. Carburettor renewal & 35 & 2.7 \\
\hline C. Cylinder head dismantling & 5 & 14 \\
\hline D. Changing of fuel pump & 17 & 4.0 \\
\hline \multicolumn{3}{|l|}{ E. Fuel injection adjustment } \\
\hline without plastic cover & 39 & 6.9 \\
\hline with plastic cover & 50 & 2.9 \\
\hline \multicolumn{3}{|l|}{ F. Petrol tank drainage } \\
\hline into an open vessel & 5 & 46 \\
\hline into petrol can & 5 & 3.5 \\
\hline
\end{tabular}

about $0.5 \mathrm{mg} \mathrm{m}^{-3}$ were measured during cleaning operations inside a tank. The average exposure ( $8 \mathrm{~h} \mathrm{TWA}$ ) of a tank cleaner was about $0.2 \mathrm{mg} \mathrm{m}^{-3}$. The exposure of the cleaner's assistant, who is not working inside the tank, was 5 times lower.

Even if the exposure to benzene during tank cleaning is much below the occupational standard, the exposure level is disquieting when the cleaner's job is considered. It is heavy work, often carried out under elevated temperature, which increases the uptake of hydrocarbons in the body. It is, therefore, of great importance that the concentration levels be reduced by improving the ventilation of the tanks.

Exposure to exhaust gases from motor vehicles

Because of imperfect combustion in the engine, small amounts of petrol are emitted in the exhaust gases. The relative hydrocarbon composition in the exhaust gases is 
similar to that in the fuel. However, there is an increase of low molecular aromatic hydrocarbons (MAYRSOHN et al., 1977). The concentration of benzene relative to the other aromatic hydrocarbons increases as a result of dealkylation of alkylbenzenes. The exhaust gases are widely spread into the environment and everybody is more or less exposed to them. It should be observed that benzene is only one of thousands of other compounds of the very complex mixture of hydrocarbons, nitrogen oxides, particulates, etc., which can be found in exhaust gases.

The exposures of taxi-drivers, street workers and employees at work places close to streets with heavy traffic have been investigated.

Taxi-drivers. Taxi-drivers are frequently exposed to exhaust gases. It was shown that the benzene concentration in the cab depends on the mode of driving. The distance from the next car ahead was an important factor. The concentration of benzene in the cab (200-400 $\left.\mu \mathrm{g} \mathrm{m}^{-3}\right)$ in dense traffic with queues was more than twice as high as the concentration (100-200 $\mu \mathrm{g} \mathrm{m}^{-3}$ ) in dense traffic without queues, e.g. no traffic lights and no cross-over stops.

The exhaust gases from other cars are the main source of exposure. The exhaust gases are brought into the vehicle by the ventilating system. There is also a contribution from the car itself which was shown from a comparison between a petrol and a diesel car in a rural area with low traffic. The benzene concentration was $5-10 \mu \mathrm{g} \mathrm{m}^{-3}$ in the petrol car and about 50\% lower in the diesel car. The content of light aromatic hydrocarbons is low in diesel fuel compared with petrol. The difference between the concentrations inside the two cars is therefore a measure of the contribution from the petrol engine. The contribution from the car itself is probably higher in an old car.

The driver himself can lower the exposure by simple measures. The most important is to keep an adequate distance from the car in front.

Street workers. Street workers are another occupational group exposed to exhaust gases with their working places in cities often situated close to the traffic. In narrow streets with congested traffic the exposure (relative to the number of cars $/ \mathrm{min}$ ) to aromatic hydrocarbons was three times higher than in wider streets with good ventilation and no queues. The exposure levels for street workers to benzene varied between 20 and $60 \mu \mathrm{g} \mathrm{m}^{-3}$. Short-time samples showed that the benzene concentration during high traffic intensity was around $100 \mu \mathrm{g} \mathrm{m}^{-3}$. Precautions to reduce the exposure for the workers have been tested. The best results were obtained when the nearest lane was closed during work, in which case the concentration was reduced by. one third. Screening the workplace from the traffic by a barrier (plastic film, about $1.5 \mathrm{~m}$ height) was less effective.

Work places near streets with busy traffic. Many work places, e.g. shops, are situated close to streets with intense traffic. The employees are daily exposed to exhaust gases entering the work place through natural draughts or through the ventilation system. The ventilating air inlet is often unsuitably placed. For example, at a hospital building, where the air inlet was placed on the ground floor on the wall facing a main street, the concentrations of benzene were simultaneously determined at several places inside and outside the building. The concentrations inside were about the same as those outside in the street (Fig. 2). The result indicates that the exposure levels could be reduced by 


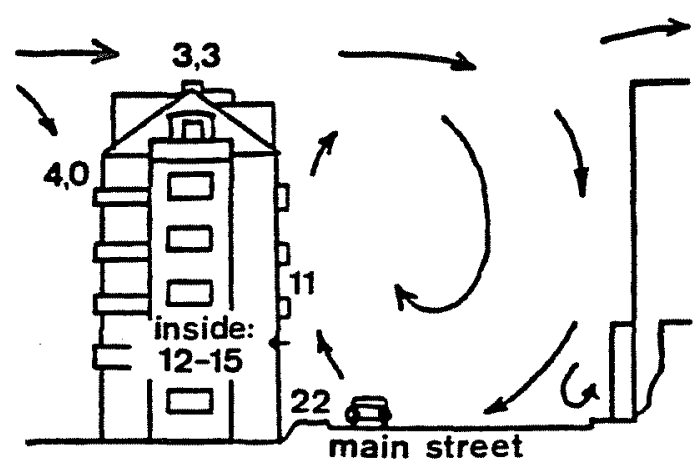

Fig. 2. The benzene concentration $\left(\mu \mathrm{g} \mathrm{m}^{-3}\right)$ inside and outside a building with the ventilating air inlet facing a main street. The dominating wind direction is indicated.

$90 \%$ if the location of the air inlet were moved from the ground floor to the top of the roof.

\section{CONCLUSIONS}

Although there is no commercial production of benzene (with two exceptions, at steel mills and at an ethylene plant) and no large benzene-consuming industry in Sweden, benzene is present at many work places where petrochemical products with varying benzene content are used. Because of the high benzene content in Swedish petrol, $\max .5 \%(\mathrm{v} / \mathrm{v})$, many workers are exposed to benzene originating from evaporated fuel and exhaust gases. The average benzene content in petrol has also increased during the last few years as a result of the decrease of the lead content. Benzene from exhaust gases is spread throughout the environment. Many employees at work places close to streets with busy traffic are exposed to elevated concentrations of benzene during their working day.

Our study shows that the exposure of all workers investigated is below the Swedish occupational standard for benzene ( $8 \mathrm{~h}$ TWA). However, the concentration levels are near or above the former temporary emergency standard in the United States $\left(3 \mathrm{mg} \mathrm{m}^{-3}\right)$. With new evidence of the adverse effects of low concentrations of benzene the occupational standard value may be lowered again in the United States. Our measurements demonstrate that the major contribution to the TWA-value is often due to special operations with elevated exposure. Simple precautions can often lower the exposure significantly.

From our study we would like to draw attention to the following conclusions.

(1) Although there are almost no 'benzene industries' in Sweden, many workers are exposed to benzene in their occupational environment.

(2) Low benzene content can give rise to high exposure under certain conditions, e.g. confined space, poor ventilation, elevated temperatures.

(3) Many workers are exposed to benzene via exhaust gases from motor vehicles.

(4) The occupational exposure to benzene can easily be lowered for many workers by simple inexpensive precautions. 


\section{REFERENCES}

BERLIN, M., GAGE, J. and Johnson, E. (1974) Scand. J. Wk environ. Hlth 11, 1-20.

Berlin, M. and Tunek, A. (1981) Criteria Document for Swedish Occupational Standards. Benzene (in Swedish). Arbete och Hälsa 1981:3. Arbetarskyddssverket, Stockholm.

Brief, R. S., Lynch, J., Bernath, T. and Scala, R. A. (1980) Am. ind. Hyg. Ass. J. 41, 616-623.

Cheremisinoff, P. N. and Morresi, A. C. (1979) Benzene: Basic and Hazardous Properties. Marcel Dekker, New York.

Collegium Ramazzini (1985) Proceedings of the International Conference on Benzene, 1983. Alan R. Liss, Inc., New York. (Am. J. ind. Med. 7, 361-492.)

CONCAWE (1981) Report No. 2/81 CONCAWE, The Hague, The Netherlands.

CONCAWE (1986) Report No. 3/86 CONCAWE, The Hague, The Netherlands.

EPA (1978) Report No. 600/1-78-061 EPA.

Gitzlaff, T. R., Batton, F. E. and Holmes, W. E. (1979) Chem. Engng 86, 117-118.

Green, J. D., LeONG, K. J. and LASkin, S. (1978) Toxic. appl. Pharmac. 46, 9-18.

Hite, M., Pecharo, M., Smith, I. and Thornton, S. (1980) Mutat. Res. 77, 149-155.

INFANTE, P. F., RINSKY, R. A., WAGONER, J. K. and Young, R. J. (1977) Lancet ii, 76-78.

IrWing, W. S., Jr and Grumbles, T. G. (1979) Am. ind. Hyg. Ass. J. 40, 468-473.

Lange, A., SMolik, R., Zatonsky, W. and SzYMANSKa, W. (1973) Int. Arch. Arbeitsmed. 31, $37-44$.

Maltoni, C., Conti, B. and Cotti, G. (1983) Am. J. ind. Med. 4, 589-630.

Mattsson, M. and Petersson, G. (1982) Int. J. environ. anal. Chem. 11, 211-219.

Mayrsohn, H., Crabtree, I. H., Kuramoto, M., Sothern, R. D. and Mano, S. H. (1977) Atmos. Environ. 11, 189-192.

Nordic ExPERT Group for Documentation of OCCuPational Exposure Limits (1981) Benzene (in Swedish). Arbete och Hälsa 1981:11. Arbetarskyddsverket, Stockholm.

NORDLINDER, R. and RAMNÄs, O. (1981) Sampling and Analysis of Benzene and Alkylbenzenes (in Swedish). Report to Swedish Work Environment Fund. Project 78/124.

Parkinson, G. S. (1971) Ann. occup. Hyg. 14, 145-153.

Petersson, G. (1982) Environ. Pollution B4, 207-217.

Phillips, C. F. and Jones, R. K. (1978) Am. ind. Hyg. Ass. J. 39, 118-128.

Picclano, D. (1979) Environ. Res. 19, 33-38.

Santesson, C. G. (1897) Arch. Hyg. Berl. 31, 336.

SHERWOOD, R. J. (1972) Br. J. ind. Med. 29, 65-69.

SNYDER, R. and Kocsis, J. K. (1975) Crit. Rev. Toxic. 3, 265-288.

VIGLIANI, E. C. and ForNI, A. (1976) Environ. Res. 11, 122-127.

ZENZ, C. (1978) Scand. J. Wk environ. Hlth 4, 103-113. 